\title{
Charting a low carbon future for shipping: A UK perspective
}

\author{
Conor Walsh ${ }^{\mathrm{a}}$, Sarah Mander ${ }^{\mathrm{b}}$, Alice Larkin ${ }^{\mathrm{b}, *}$ \\ ${ }^{a}$ National Resources Institute, Department of Agriculture Health and Environment, University of Greenwich, Medway Campus, Central Avenue, Chatham Maritime ME4 \\ 4TB, United Kingdom \\ b Tyndall Centre for Climate Change Research, School of Mechanical, Aerospace and Civil Engineering, University of Manchester, Sackville St, Manchester M13 9PL, \\ United Kingdom
}

\section{A R T I C L E I N F O}

\section{Keywords:}

Shipping scenarios

$\mathrm{CO} 2$ reduction

Shipping emissions

Decarbonisation

Climate change

Carbon budgets

\begin{abstract}
A B S T R A C T
Projected growth in the international shipping industry is set to outstrip $\mathrm{CO}_{2}$ reductions arising from incremental improvements to technology and operations currently being planned and implemented. Using original scenarios, this paper demonstrates for the first time that it is possible for a nation's shipping to make a fair contribution to meeting global climate change commitments, but that this requires transformation of the sector. The scale and nature of technology change varies depending on the level of demand and how this is satisfied. The scenarios show that to develop successful marine mitigation policy, it is essential to consider the interdependencies between ship speed, level and pattern of demand for services, and the extent and rate of innovation in propulsion technology. Across the scenarios, it is difficult to foresee how deep decarbonisation can be achieved without an immediate, fleet-wide speed reduction; and a land-based energy-system transition strongly influences shipping demand, which in turn, influences the extent of required low-carbon propulsion technology change. Setting the industry on a $2{ }^{\circ} \mathrm{C}$ heading requires multifaceted and near-term changes in the shipping sector, but these are unlikely to materialise without a major shift by stakeholders to realise new and innovative deep decarbonisation policies in the coming decade.
\end{abstract}

\section{Introduction}

The globalised character of modern societies links economic growth to shipping activity. Between 1950 and 2005, the productivity of the shipping industry in terms of seaborne imports increased by $4.7 \%$ per annum [36]. The past half a century has seen the emergence of key trading nations such as Japan and more recently China [40]. Over the same period, growth in demand for shipping has resulted in an eightfold increase in the total capacity of the global fleet, with more and bigger vessels, the latter for the benefit of economies of scale. These developments have impacted on the character of supply chains. For example, rising demand for oil and the location of refineries closer to end markets has led to the shipping of large quantities of crude oil [9]. Over the past decades these and other changes such as containerisation, have increased the distances over which goods are shipped.

Shipping has been instrumental in facilitating trade between developed and developing countries. In the 1970s, developing countries predominately supplied raw materials; by 2012 the quantity of goods unloaded and loaded by developing countries was approximately $60 \%$ of global trade [37], reflecting the expansion of trade of intermediate goods amongst developing nations. Taken together, these changes have significant implications for the growth of shipping greenhouse gas emissions. Eyring et al. [13] estimate that between 1950 and 2001 the $\mathrm{CO}_{2}$ emissions attributable to shipping increased over four-fold.

Looking ahead, the International Maritime Organisation (IMO), has implemented two energy efficiency regulations, the Energy Efficiency Design Index (EEDI) and the Ship Energy Efficiency Management Plan (SEEMP). Analysis suggests, however, that these policies will not reduce shipping's absolute $\mathrm{CO}_{2}$ emissions, due to growth in transport demand and the slow pace of technology innovation [33]. This is despite the IMO's aim for the shipping sector to make its fair and proportionate contribution to keeping global mean temperatures below $2{ }^{\circ} \mathrm{C}$ (see Morooka [24] for example). Within this global context, the High Seas research project focused on understanding how 'UK shipping' may cut $\mathrm{CO}_{2}$ in line with a $2{ }^{\circ} \mathrm{C}$ goal. The insights from this work have relevance beyond the UK and related policy frameworks, given the international nature of shipping.

Within this paper 'UK shipping' is defined as the freight work (i.e. tonne kilometres) associated with transporting goods from the country of loading to the UK (imports), as well as trade around the UK. Imports are chosen as the UK is a net importer of materials and imports arguably represent a closer reflection of the resource demands within a region

\footnotetext{
* Corresponding author.

E-mail address: alice.larkin@manchester.ac.uk (A. Larkin).
} 
and UK domestic trade is included to reflect the movement of goods around the UK.

A set of qualitative and quantitative scenarios were developed to explore ways in which shipping's $\mathrm{CO}_{2}$ can remain within a carbon budget commensurate with $2{ }^{\circ} \mathrm{C}$. The scenarios aim to inform policy and decision making by expressly focusing on energy consumption and $\mathrm{CO}_{2}$ emissions change, without detailed economic estimates. While economic assessments can complement this work, this study avoids introducing the very large uncertainties related to costing technologies, operational and demand-side change up to forty-years hence. This paper initially provides an overview of other shipping $\mathrm{CO}_{2}$ scenarios before moving on to describe the challenges faced by the sector contributing to the global $2{ }^{\circ} \mathrm{C}$ goal. The method section outlines the scenario process and the results section presents scenario narratives, and quantification including cumulative $\mathrm{CO}_{2}$ emissions. The discussion compares the outcomes of the scenarios, concluding by drawing out key lessons for $\mathrm{CO}_{2}$ mitigation options available to the shipping system.

\subsection{Future shipping emissions}

A few notable studies have considered implications of climate change mitigation for shipping, [13,14,34,6,8]. In the IMO's Third Greenhouse Gas study, global shipping emissions are projected to 2050 [34], framed by the Intergovernmental Panel on Climate Change (IPCC)'s 'Representative Concentration Pathways' (RCPs) and 'Shared Socioeconomic Pathways (SSPs) [39]. Future demand for shipping is projected and emissions estimated taking into account mitigation measures. The results suggest $\mathrm{CO}_{2}$ emissions in 2050 will lie between 810 and 2,800, $\mathrm{Mt} \mathrm{CO}_{2}$, compared with $810 \mathrm{Mt} \mathrm{CO}_{2}$ in 2012. The lower value is achieved within the context of RCP 4.5, with its high uptake of liquid natural gas and significant efficiency $(60 \%)$ improvements in the fleet relative to 2012 .

Drawing on the Special Report on Emission Ecenarios (SRES) $[14,25]$ project shipping emissions based on assumptions on demand for shipping, linked to global GDP, and technology. While the range of absolute emissions projected in Eyring et al. [14] is not as broad as in Smith et al. [34], the projected growth in emissions (relative to 2012) is comparable to three of the four business as usual emission pathways described in Smith et al. [34]. Crucially neither demonstrates an absolute decrease in $\mathrm{CO}_{2}$ from their respective base year by 2050 .

Paxian et al. [27] project global shipping emissions using a bottomup ship movement inventory, supplemented with a route finding algorithm and ship characteristic data. Shipping emissions are projected to range between 859 and $1525 \mathrm{Mt} \mathrm{CO}_{2}$ in 2050 for both a 'clean technology' and 'business as usual' projection respectively.

Focusing on economics, Eide et al. [11] project shipping emissions to 2030 in conjunction with different mitigation measures, to identify potential costs associated with sectoral decarbonisation. They estimate that by 2030 global shipping emissions can be reduced by $33 \%$ (from a 2010 baseline) without incurring an additional marginal cost. The authors also suggest an upper limit on the cost effectiveness of carbon reduction, beyond which additional costs result in a marginal increase in emission savings. The importance of fiscal and regulatory measures that pressurise the industry over and above any anticipated fuel price increases are highlighted.

The studies outlined focus on emissions in 2050 and principally on a 2050 end-point, as opposed to considering cumulative emissions. However, it is the cumulative emissions of $\mathrm{CO}_{2}$ over time that have a much closer relationship to the climate outcome in terms of temperature [35].

\subsection{Cumulative emissions and emission pathways}

As emissions of $\mathrm{CO}_{2}$ are long-lived, the climatic response to $\mathrm{CO}_{2}$ depends on its accumulation in the atmosphere over time. Estimates of the temperature response to cumulative emissions vary but there is a
Table 1

Shipping $\mathrm{CO}_{2}$ cuts, taken from [2].

\begin{tabular}{ll}
\hline Year & Reduction relative to 2010 \\
\hline 2010 & 0 \\
2020 & $15 \%$ \\
2030 & $40 \%$ \\
2040 & $70 \%$ \\
2050 & $85 \%$ \\
\hline
\end{tabular}

general consensus that the temperature response to cumulative emissions is relatively constant over time [1]. The benefit of a 'cumulative emissions' framing is it connects limits on $\mathrm{CO}_{2}$ across a particular time frame with the likelihood of avoiding a given average global temperature increase.

With the ratification of the Paris Agreement, nations are committed to keeping global mean temperatures to well below $2{ }^{\circ} \mathrm{C}$ [38]. Prior to the Paris Agreement, a statement from a senior IMO representative said that the shipping industry should "make its fair and proportionate contribution" to the levels of mitigation deemed necessary to reduce the likelihood of a global mean temperature rise commensurate with averting dangerous climate change [19]. Taking emission reduction pathways commensurate with $2{ }^{\circ} \mathrm{C}$, Anderson and Bows [2], derived proportional $\mathrm{CO}_{2}$ pathways for the shipping sector for a $50 \%$ likelihood of maintaining global temperature increase to within $2{ }^{\circ} \mathrm{C}$ above preindustrial levels (Table 1 ). The scenarios presented in this paper build on that analysis to show how UK shipping $\mathrm{CO}_{2}$ could be reduced to be consistent with the $\mathrm{CO}_{2}$ cuts in Table 1 .

The method of assuming global emission reductions for the aggregate of all sectors allows the assigning of appropriate targets for international shipping at both global and a national scale. This is in the absence of an agreed definition on how to apportion the global emissions burden differentially to nations [15].

\section{Method}

Each scenario is described by a qualitative narrative, with quantitative indicators to capture freight work, energy consumption and cumulative $\mathrm{CO}_{2}$ emissions. The method takes a backcasting approach $[29,30]$ applied in five steps with iteration to ensure that the cumulative emissions pathway remains within the boundary set by Table 1. This builds on related work focusing on the whole energy system [23] as well as specific sectors [5].

The first step in the process is to define the cumulative $\mathrm{CO}_{2}$ budget. The second is to understand the present day shipping system, in particular demand for shipping, freight work, energy demand, fuel consumption and $\mathrm{CO}_{2}$ emissions produced; this is achieved using a bespoke model, ASK C [41]. The third step is to identify driving forces that could influence $\mathrm{CO}_{2}$ reduction in the shipping sector. The driving forces are articulated in a set of narratives in step four, quantified using the ASK C model in the final step. The scenarios were informed by stakeholders and model assumptions about the deployment of new technology within the shipping sector were based on technology roadmaps, which were co-produced with stakeholders [16]. More detail on the full scenarios can be found in Bows-Larkin et al. [4].

\subsection{Identification of decarbonisation themes}

Carbon emissions from shipping, like all other sectors, will change depending on three principal factors: demand for shipping services (e.g. higher demand for transported goods can result in more journeys and/ or larger ships), new technology (e.g. alternative fuels, energy efficiency measures) and operational change (e.g. logistics and ship speed). Following a literature review and preliminary scenario development considering these three principal factors, a panel of academics and 
shipping industry stakeholders convened to inform and critically review initial scenario assumptions. Aspects of the scenarios were then modified although the emerging scenarios quickly incorporated some key themes: a self-sufficient UK; increased use of information technology (IT) and communications; slow steaming; alternative port configurations (hub and spoke vs distributed ports); and the influence of the military on technology, supporting the diffusion of marine nuclear power.

\subsection{Articulation of scenario narratives}

Scenario narratives were developed by the project team, framed around a set of questions.

- What has changed?

- The time period during which these changes occurred.

- Why has this happened?

- How have changes been realised?

- Who is driving change?

The narratives were translated into a set of quantitative assumptions as inputs into the ASK C model. The technology elements were informed by a technology road-mapping workshop $[16,18]$. Technology roadmapping is a structured process whereby a set of stakeholders define a transition to a stated end-point, focusing on the milestones and how they may be achieved [28]. The workshop described in detail in High Seas [31] developed technology roadmaps for 3 different ship types: small ships, containers and bulk ships, and for new and retro-fit vessels. These roadmaps fed into the technology modules within ASK C, informing assumptions including technology mix, timeframe and replacement rate.

\subsection{Scenario quantification}

Similar to CCC [8], changes to freight work associated with UK imports reflect changes to both the traded quantities and the geographic distribution of trading partners. ASK C estimates the $\mathrm{CO}_{2}$ emissions for a given scenario using a set of input assumptions. The method for calculating future shipping emissions is described in Walsh et al. [41]. Table 2 provides an overview of the model assumptions.

\subsection{Scenario descriptions}

The three distinct decarbonisation scenarios share some common

Table 2

Main determinants for shipping $\mathrm{CO}_{2}$ emissions within the scenarios.

\begin{tabular}{clll}
\hline Trade patterns & $\begin{array}{l}\text { Ship } \\
\text { Characteristics }\end{array}$ & $\begin{array}{l}\text { Technology and } \\
\text { deployment }\end{array}$ & Fuel \\
\hline $\begin{array}{c}\text { Percentage of } \\
\text { trade by } \\
\text { world } \\
\text { region }\end{array}$ & $\begin{array}{l}\text { Ship size } \\
\text { (dwt) }\end{array}$ & $\begin{array}{l}\text { Ship Delivery and } \\
\text { removals rates }\end{array}$ & Engine/fuel type \\
$\begin{array}{c}\text { Distance per } \\
\text { tonne (by } \\
\text { region) }\end{array}$ & Engine size & $\begin{array}{l}\text { Energy reduction } \\
\text { due to new build } \\
\text { technology (\%) }\end{array}$ & $\begin{array}{l}\text { Specific fuel } \\
\text { Consumption } \\
\text { (g/kWh) }\end{array}$ \\
& Engine loading (\%) & $\begin{array}{l}\text { Energy reduction } \\
\text { due to operations } \\
\text { (\%) }\end{array}$ & $\begin{array}{l}\text { Carbon content } \\
\text { (kg C/kg fuel) }\end{array}$ \\
& & $\begin{array}{l}\text { Energy reduction } \\
\text { due to retro-fit } \\
\text { technology (\%) } \\
\text { Energy reduction } \\
\text { due to renewable } \\
\text { technology (\%) }\end{array}$ & $\begin{array}{l}\text { Percentage of } \\
\text { bio-derived Fuel }\end{array}$ \\
& $\begin{array}{l}\text { Capacity } \\
\text { utilisation (\%) }\end{array}$ & Speed reduction (\%) & \\
& & &
\end{tabular}

features but offer contrasting visions of demand and technology change, as well as wider supply chain and logistical system changes.

\subsubsection{Big World (S1)}

The Big World scenario (S1) assumes a continuation of the globalisation of world trade in which demand for shipping remains buoyant. This scenario is distinguished primarily through the average transit distance associated with UK trade increasing as competition between domestic and international producers incentivises the continued exploitation of more distant markets. The UK is much less dependent on short sea shipping than at present. Economies of scale result in continued growth in vessel size. Consolidation of shipping capacity by larger companies runs the risk of oligopolies on certain routes, increasing the pressure on port state control to ensure compliance and best practice. Logistical support is mature in tandem with IT and satellite technology. Such support is provided in real time on most voyages which, and along with the provision of dedicated berthing services at ports, incentivises a drastic reduction in ship speeds, particularly for container vessels. With increased containerised trade this scenario projects an increase in domestic trade of containers on smaller ships, following a hub and spoke configuration. The interconnections between modes is much more efficient than at present, with ports unloading cargo and loading onto other modes with much greater efficacy, minimising time spent at port. The UK has decarbonised its energy system following an established 'Carbon Capture and Storage (CCS)' decarbonisation scenario [10], which represents the highest level of import demand, in keeping with the theme of globalisation. While the UK attempts to dematerialise through adherence to the waste hierarchy, there remains continued demand for containerised goods due both to demand for manufactured goods as well and the displacement of dry cargo, such as bulky forestry and steel products, by containerised trade.

\subsubsection{Full Speed Ahead (S2)}

The Full Speed Ahead scenario (S2) differs from the others in that it does not assume a drastic departure from the baseline year (2010) trading partners, with some notable exceptions, such as oil being sourced from more distant markets. Within this scenario the UK decarbonises following the 'Markal' decarbonisation scenario [10], which envisions a diverse range of demand and supply based measures, including a high proportion of nuclear power. The shipping sector adapts to a more challenging environment in this scenario. For example, UK demand for containerised goods fluctuates while the cost of marine fuel increases steadily. Amid economic difficulties, shipping contends with a continued threat of piracy which is particularly prevalent along the Suez route. By 2030 the demand for container transport work has returned to 2010 levels, while ships are larger and have reduced speed by $10 \%$. This, in conjunction with the reduction in demand for fossil commodities, and the uptake of retrofit technologies, contributes to a reduction in emissions relative to 2010. A distinguishing feature of this scenario is the emergence of a key new-build technology, namely nuclear powered ships. In this scenario, shipping benefits from technical progress in other sectors, particularly the development of modular nuclear reactors. Cooperation between different economic sectors as well as changes in societal attitudes allows commercial nuclear vessels to emerge by 2030 . This requires engagement from ship builders, breaker yards and port and terminal operators, with both practical and regulatory aspects. The expansion of nuclear shipping necessitates changes to standard operating procedures for berthing, maintenance and resale of vessels. In contrast to the first scenario, nuclear shipping allows vessel speed to be maintained, reducing pressure on logistic systems to optimise routing to reduce emissions.

\subsubsection{Where the Wind Blows (S3)}

Where the Wind Blows (S3) is distinguished by an increase in 
domestic self-sufficiency, and a reversal of the global trend towards greater globalisation and a future in which decarbonisation is less contingent on global developments than the other scenarios. While the UK has traditionally been reliant on short sea shipping, this scenario gradually increases this degree of dependence; the UK mostly trades within Europe. This results in a consistent reduction in the overall freight work associated with UK imports relative to the base year. This scenario envisions economic policies across Europe, to bolster manufacturing and employment, and convergence in prices and labour costs decreasing the advantage of outsourcing, making the "near sourcing" of production closer to markets more economical. Furthermore, a significant increase in ship building and retrofitting of new, including wind-propulsion, technologies is facilitated by resurgence within the European ship building sector and the construction of new shipyards and dry dock facilities. This scenario presents a more diverse shipping industry where the apparent trends of consolidation and increased ship size are reversed. By 2050 shipping demand is met by a large number of different companies that apply a range of technologies to increase the fuel efficiencies of their vessels. Both the increased reliance on short sea shipping and the revitalisation of European ship building have enhanced the viability of smaller ships, with the average size of ship servicing the UK decreasing until 2050. In keeping with the theme of efficiency, this scenario envisions that the UK decarbonises according to the 'high renewable, high efficiency' scenario [10].

The scenarios are summarised in Table 3, and in Figs. 2-4. Characteristics are compared with the baseline year of 2010 .

\section{Scenario results}

Each of the decarbonisation scenarios reflects contrasting visions of how the supply and demand of UK shipping may respond to the decarbonisation challenge under different narratives. The impact of the scenarios on the quantity of material unloaded at UK ports by 2050 is presented in Fig. 1.

All scenarios have a $\geq 15 \%$ reduction in imported and domestic trade 2050 (Fig. 1). Deep-sea trade is important in S1 while short sea is more important in $\mathrm{S} 3$, yet both project similar overall tonnage estimates by 2050. Comparing 2030 and 2050 for S1 and S3, the impact of national energy system decarbonisation with reduced imports of oil and coal (as dry bulk) is offset by increasing demand for other goods such as containers or RoRo. In S2, the reduced demand for liquid gas and slow growth of container demand, following a decrease in the 2030s, results in the lowest trade by 2050 across scenarios. However trade alone presents a limited picture of the demand for shipping services; taking into account transport distance to estimate freight work (Fig. 2) provides a better indication of both the energy demand associated with UK shipped imports and demand for shipping services.

Comparing overall scenario freight work demand highlights the importance of transport distance and the choice of trading partners (Fig. 3). S1 and S2 have extended supply chains to incorporate new trading partners, increasing freight work by 2050. Comparing S1 and S3 demonstrates how similar quantities of physical trade can have significant divergence in freight work demand. The predominance of the container category is the result of both the quantity traded and, as importantly, transport distances involved.

In S1, haul distance almost doubles due to the importance of American and Asian trading partners over European markets in contrast to the UK's trading position in 2010, where most tonnage arrives by short sea shipping. However the difference in haul length between the deep-sea and the short sea trade suggests that substituting material imported from Europe for deep-sea trades will have a significant impact on associated freight work (Figs. 2 and 3). Changes to average haul length may reflect both increasing imports of additional goods sourced from more distant trading partners, or the substitution of existing material. The impact of the latter will depend on the quantity, type of good and the distribution of new trading partners.
Due to their varying demand (Table 4), the scenarios differ by propulsion technologies in order to remain within the cumulative $\mathrm{CO}_{2}$ budget. Fig. 4 illustrates the relative impact of different energy saving measures. It distinguishes between energy saved by technological and operational measures (such as hull design) and the remaining energy satisfied by low carbon technologies, conventional and bio-derived fuel.

Figs. 4 and 5 demonstrate how each scenario uses different combinations of energy and $\mathrm{CO}_{2}$ mitigation measures to decarbonise. Fig. 4 illustrates the energy saving measures, whereas Fig. 5 describes how the remaining energy consumption is met by different technologies. As the impact of energy efficiency measures are calculated in terms of per cent reductions, the impact of a group of specific emission reduction or energy efficiency measures is not additive. To compensate for this, the contribution of each group of emission saving categories is distinguished from total energy saved using the log rule. The energy saved by different mitigation measures as well as the actual energy supplied by propulsion technologies is shown in Figs. 4 and 5. S1 illustrates how a reduction in speed is the main contributor to energy demand reduction. The penetration of nuclear vessels has the greatest reduction in energy demand within S2, but no impact before 2030. S3 illustrates that while stringent technological and operational measures remain essential; in absolute terms the reduction in demand for shipping services is the most important factor.

\subsection{Cumulative $\mathrm{CO}_{2}$ reduction}

Figs. 6-8 show all three scenarios have significant reductions in $\mathrm{CO}_{2}$ by 2050 , but the rate of decrease differs depending on the type of mitigation measure undertaken, when they are implemented and uptake levels.

$\mathrm{CO}_{2}$ cuts in $\mathrm{S} 1$ are primarily attributable to a reduction in speed (Fig. 5), and most pronounced for container vessels. Within this scenario, container shipping is the largest contributor to freight work demand and the focus of significant $\mathrm{CO}_{2}$ mitigation measures. Within S1, changes in container ship speed and size, and energy saving technologies are embedded early, becoming more extensive as the containerised trade grows.

Prior to 2030, emission reductions in S2 are from a reduced demand for freight work, increase in ship size, reduction in speed, and energy saving technologies. However by 2050, the emergence of nuclearpowered ships has the largest impact on $\mathrm{CO}_{2}$. This occurs in an environment where an increase in transport demand is met through an increase in ship size and capacity utilisation. Non-nuclear ships also incorporate $\mathrm{CO}_{2}$ reduction technologies, such as waste heat recovery, counter rotating propellers and hull anti-fouling.

S3 illustrates the importance of demand based responses whereby a reorientation of trading partners reduces the distances goods are shipped. Reductions in demand mean that other mitigation measures, such as renewable technologies, have greater impact. By 2050, S3 includes retrofit technologies, renewable technologies and bio-derived fuel to collectively satisfy approximately $30 \%$ of primary energy demand, a greater quotient than the other scenarios.

As the climatic impacts of carbon emissions are due to their cumulative presence in the atmosphere, it is not strictly necessary for emissions to remain within the pathways, instead the "area under the curve" as delineated by the cumulative emission pathways, must be adhered to; all the scenarios developed fit with this criteria.

Figs. 2 and 8 show the reduction in transport demand is the main contributor to a reduction in energy demand and consequently cumulative $\mathrm{CO}_{2}$. Also, a change in trading partners and the incorporation of a diverse range of $\mathrm{CO}_{2}$ mitigation measures can maintain an existing supply of materials without some of the more radical modifications to the shipping sector envisioned in S1 and S2. 
Table 3

Main scenario characteristics and end point $\mathrm{CO}_{2}$ emissions by 2050 .

\begin{tabular}{|c|c|c|c|}
\hline Characteristic & Big World (S1) & Full speed ahead (S2) & Where the wind blows (S3) \\
\hline \multicolumn{4}{|c|}{ UK Shipping Characteristics in 2050} \\
\hline $\begin{array}{l}\text { Shipping market } \\
\text { Drivers for decarbonisation of } \\
\quad \text { the shipping sector }\end{array}$ & $\begin{array}{l}\text { Greater importance of deep-sea trade. } \\
\text { Regulation and competition to incentivise } \\
\text { fuel efficiency gains. }\end{array}$ & $\begin{array}{l}\text { Both deep and short sea shipping important. } \\
\text { Increasing costs of marine fuel. }\end{array}$ & $\begin{array}{l}\text { Decline in deep-sea trade routes. } \\
\text { Strict fuel efficiency targets enforced at port } \\
\text { level. }\end{array}$ \\
\hline UK imports & $\begin{array}{l}40 \% \text { reduction in wet and dry bulk imports } \\
\text { (from 2010) as a consequence of energy } \\
\text { scenario. Doubling of quantity of } \\
\text { containerised goods. }\end{array}$ & $\begin{array}{l}26 \% \text { reduction in overall tonnage relative to } \\
2010.10 \% \text { increase in demand for non-energy } \\
\text { commodities. }\end{array}$ & $\begin{array}{l}13 \% \text { reduction in overall tonnage relative to } \\
2010 . \\
27 \% \text { increase in non-energy goods, mostly } \\
\text { associated with RoRo and containerised trade. }\end{array}$ \\
\hline Trading partners & $\begin{array}{l}\text { Extension of trade routes to encompass new } \\
\text { markets; more trade with Central and South } \\
\text { America, the Caribbean, North East Asia } \\
\text { and India; less trade with Europe and } \\
\text { Africa. }\end{array}$ & $\begin{array}{l}\text { More trade with North America for certain } \\
\text { commodities but no drastic change in trading } \\
\text { partners. } \\
\text { Some routes are longer as a precaution } \\
\text { against piracy. }\end{array}$ & $\begin{array}{l}\text { Regionalisation results in dominance of short } \\
\text { sea shipping; more trade within the EU. }\end{array}$ \\
\hline Freight Work & $\begin{array}{l}60 \% \text { increase on } 2010 \text { levels; } 45 \% \text { of freight } \\
\text { work arises from shipping of containers. }\end{array}$ & Negligible change relative to 2010 levels. & $64 \%$ reduction relative to 2010 levels. \\
\hline \multicolumn{4}{|l|}{ Vessels by 2050} \\
\hline Size of vessels & $\begin{array}{l}\text { The overall mean container ship is } \sim 3 \\
\text { times } 2010 \text { size; other ships double in size. }\end{array}$ & $\begin{array}{l}\text { The average bulk and container ships size } \\
\text { doubles by } 2050 \text {. }\end{array}$ & $\begin{array}{l}\text { Ship size decreases by at least } 50 \% \text { for } \\
\text { vessels }>5000 \mathrm{dwt} \text {. }\end{array}$ \\
\hline Ship speed & $\begin{array}{l}50 \% \text { reduction for container vessels; } 20 \% \\
\text { reduction for other vessels. }\end{array}$ & $20 \%$ reduction for containerised vessels. & $20 \%$ reduction for all vessels. \\
\hline Cargo load factors & $\begin{array}{l}30 \% \text { increase in utilisation of container } \\
\text { vessels. }\end{array}$ & $\begin{array}{l}\text { Increased utilisation capacity of container } \\
\text { vessels post } 2040 \text {. }\end{array}$ & No change. \\
\hline Fleet replacement & $90 \%$ turnover of fleet by 2050 . & $90 \%$ turnover of fleet by 2050 . & $100 \%$ turnover of fleet by 2050 . \\
\hline \multirow[t]{2}{*}{ New build technology } & $\begin{array}{l}\text { Container vessels }-10 \% \text { improvement in } \\
\text { energy efficiency; Speed reduction viewed } \\
\text { as preferable to investment in technology. }\end{array}$ & $\begin{array}{l}\text { Prior to } 2030 \text { minimal new build technology } \\
\text { installed. } \\
\text { Nuclear ships emerge } 2030-2035 \text { and } \\
\text { gradually penetrate fleet. Majority of tankers } \\
\text { and } \sim 30 \% \text { of container and dry bulk fleet } \\
\text { assumed to be nuclear powered. }\end{array}$ & $\begin{array}{l}\text { All ships assumed to benefit from a suite of } \\
\text { technologies such as contra-rotating propellers, } \\
\text { refinement of hull lines etc. }\end{array}$ \\
\hline & $\begin{array}{l}\text { Other vessels }-30 \% \text { improvement } \\
\text { (propeller optimisation and hull design). }\end{array}$ & $\begin{array}{l}\text { Non-nuclear new builds assumed to be } 30 \% \\
\text { more energy efficient by } 2050 \text {. }\end{array}$ & \\
\hline \multirow[t]{2}{*}{ Retrofit technologies } & $\begin{array}{l}\sim 10 \% \text { reduction in energy intensity for all } \\
\text { container ships and } 20 \% \text { reduction for } \\
\text { other ships. }\end{array}$ & $\begin{array}{l}\sim 20 \% \text { reduction in emission intensity applied } \\
\text { to all non- nuclear ships. (This is an increase } \\
\text { from } 2030 \text {, where approximately half the fleet } \\
\text { was assumed to benefit from retrofit } \\
\text { technology). }\end{array}$ & $\begin{array}{l}\text { Large array of diverse technologies such as hull } \\
\text { coating, variable speed pumps and fans, waste } \\
\text { heat recovery, engine tuning, fuel injection, } \\
\text { improved rudder efficiency monitoring, hybrid } \\
\text { energy systems, etc. Rapid uptake of new } \\
\text { technologies as they become available. }\end{array}$ \\
\hline & $\begin{array}{l}\text { This is a compound value reflecting a } \\
\text { combination of technologies including } \\
\text { waste heat recovery, engine tuning, fuel } \\
\text { injection, improved rudder propeller } \\
\text { integration, etc. }\end{array}$ & $\begin{array}{l}\text { As in Scenario } 1 \text { reflects overall impact of } \\
\text { multiple individual measures. }\end{array}$ & $\begin{array}{l}\text { Results in approximately } 11 \text { (dry bulk) }-20 \% \\
\text { (container) reduction in energy intensity. }\end{array}$ \\
\hline Renewable propulsion & $\begin{array}{l}\text { Wind power or wind assist assumed to } \\
\text { reduce energy demand by } \sim 10 \% \text { across all } \\
\text { vessels. }\end{array}$ & $\begin{array}{l}\text { Wind powered or wind assisted is estimated to } \\
\text { reduce energy demand by } \sim 10 \% \text { across non- } \\
\text { nuclear vessels. }\end{array}$ & $\begin{array}{l}\text { Wind powered or wind assisted is assumed to } \\
\text { reduce energy demand by } \sim 10 \% \text { across all } \\
\text { vessels. }\end{array}$ \\
\hline Fuel & $\begin{array}{l}\text { HFO with } 10 \% \text { biofuel (main engines and } \\
\text { boilers); Marine Diesel Oil (MDO) with 10\% } \\
\text { biofuel for auxiliary engine. }\end{array}$ & $\begin{array}{l}\text { HFO (main engines and boilers); MDO with for } \\
\text { auxiliary engine. 50\% bio-derived fuel for } \\
\text { RoRo. }\end{array}$ & $\begin{array}{l}\text { HFO with } 20 \% \text { biofuel (main engines and } \\
\text { boilers); MDO with } 20 \% \text { biofuel for auxiliary } \\
\text { engine. } 50 \% \text { bio-derived fuel for ships } \\
\text { transporting bio-energy. } \\
\text { All Auxiliary boilers supplied by bio-fuel. }\end{array}$ \\
\hline \multirow[t]{2}{*}{$\begin{array}{l}\text { Operational measures } \\
\text { (excluding slow- } \\
\text { steaming) }\end{array}$} & $\begin{array}{l}8 \% \text { reduction in energy intensity for } \\
\text { containers and } 14 \% \text { reduction for other } \\
\text { ships. }\end{array}$ & $\begin{array}{l}14 \% \text { reduction in energy intensity applied to } \\
\text { all non-nuclear ships. }\end{array}$ & $\begin{array}{l}\text { As in Scenario } 1 \text { reflects overall impact of } \\
\text { multiple individual measures. }\end{array}$ \\
\hline & $\begin{array}{l}\text { Reflects to a combination of measures } \\
\text { including weather routing, optimised trim/ } \\
\text { draft, condition based maintenance etc. }\end{array}$ & $\begin{array}{l}\text { As in Scenario } 1 \text { reflects overall impact of } \\
\text { multiple individual measures. }\end{array}$ & $\begin{array}{l}14 \% \text { reduction in energy intensity applied to } \\
\text { half the fleet. }\end{array}$ \\
\hline Emission Estimate 2050 & $3.21 \mathrm{Mt} \mathrm{CO}_{2}$ & $2.58 \mathrm{Mt} \mathrm{CO}_{2}$ & $1.86 \mathrm{Mt} \mathrm{CO}_{2}$ \\
\hline $\begin{array}{l}\text { Cumulative Emissions } \\
(2010-2050)\end{array}$ & $323 \mathrm{Mt} \mathrm{CO}_{2}$ & $309 \mathrm{Mt} \mathrm{CO} 2$ & $268 \mathrm{Mt} \mathrm{CO}_{2}$ \\
\hline
\end{tabular}

\section{Discussion}

While each scenario depends on a group of emission mitigation options to achieve decarbonisation, there are key differences between scenarios, relating to speed, transport demand reduction, $\mathrm{CO}_{2}$ mitigation technologies and impacts of for wider system change.

\subsection{Speed}

S1 confirms that a reduction in ship speed is an effective means to cut $\mathrm{CO}_{2}$ emissions [9]; but speed cannot be considered in isolation, particularly when set in a context of global supply chains. Slower ship speed reduces the frequency of vessels calling at ports depending on the time spent at sea. To maintain the same frequency of supply necessi- 


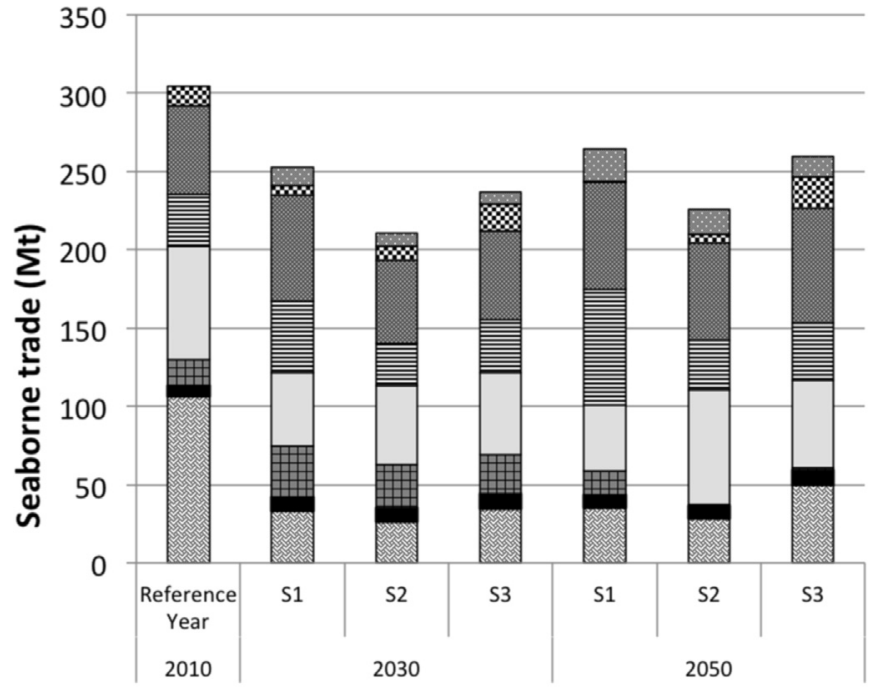

图 Oil

$\square$ Dry Bulk

- Other Liquid Bulk $\boxplus$ Liquid Gas

冈 Gen Cargo

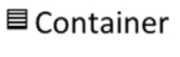

Bio-Energy

Fig. 1. Comparison of imported and domestic tonnage in 2010 and by 2030 and 2050 (Mt). S1, S2 and S3 refer to the three scenarios.

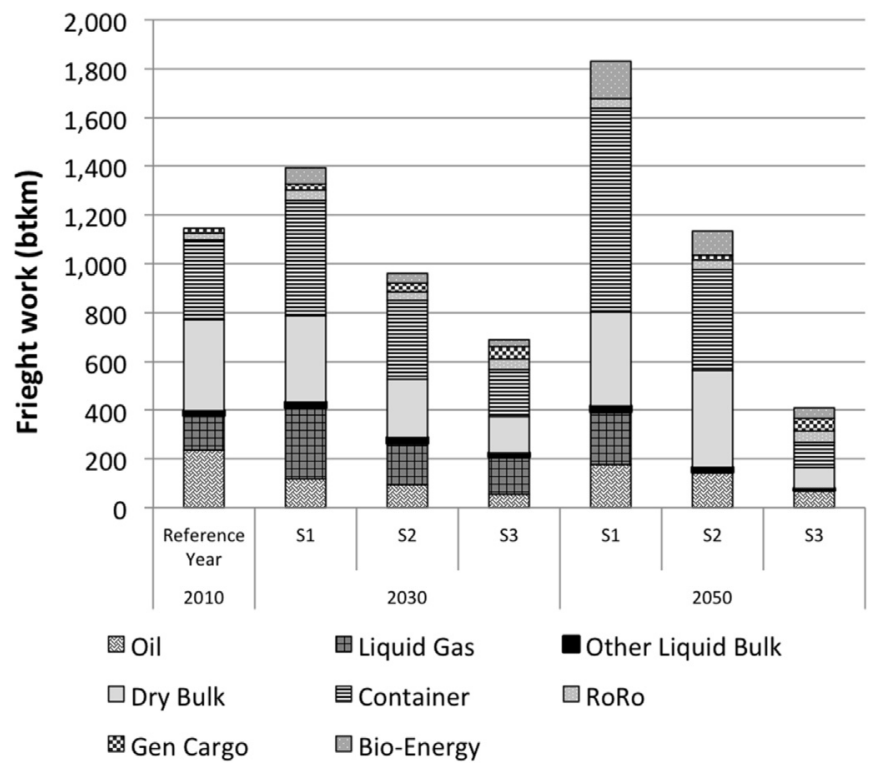

Fig. 2. Comparison of freight work demand across the scenarios (billion tkm).

tates additional or larger ships, which could increase $\mathrm{CO}_{2}$ [9]. For $\mathrm{S} 1$ to remain within the set $\mathrm{CO}_{2}$ budgets, no additional ships are added, rather, an increase in ship size is used instead. An incremental decrease in speed and increasing ship size allows time for supply chains to accommodate longer delivery times or plan new infrastructure such as warehousing. However, there are technical constraints to be considered. For instance, engines are not optimised for the kinds of significantly slower speeds that can deeply cut $\mathrm{CO}_{2}$, so, the installation of slow steaming upgrade kits would be needed to allow engines to accommodate a lower engine loading [21]. In practical terms, the widespread uptake of slow steaming would benefit from policies such as 'slow speed clauses' within time charters becoming standard practice to maintain services. Ports around the world could also facilitate such changes through, for example, policies targeting the provision of dedicated or virtual berths, again to maintain services and smooth throughput [26].

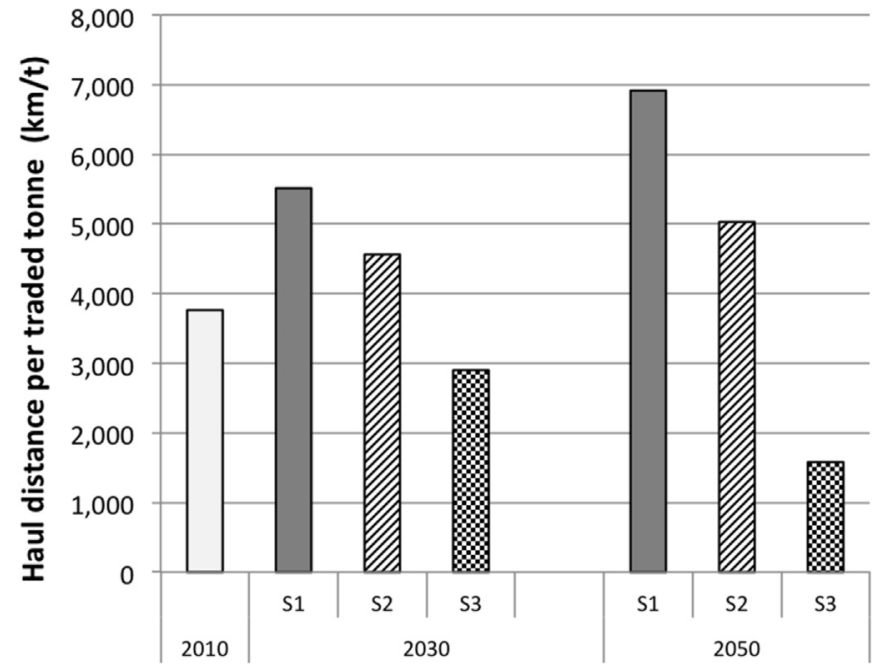

Fig. 3. Average haul distance per traded tonne across the scenarios $(\mathrm{km})$.

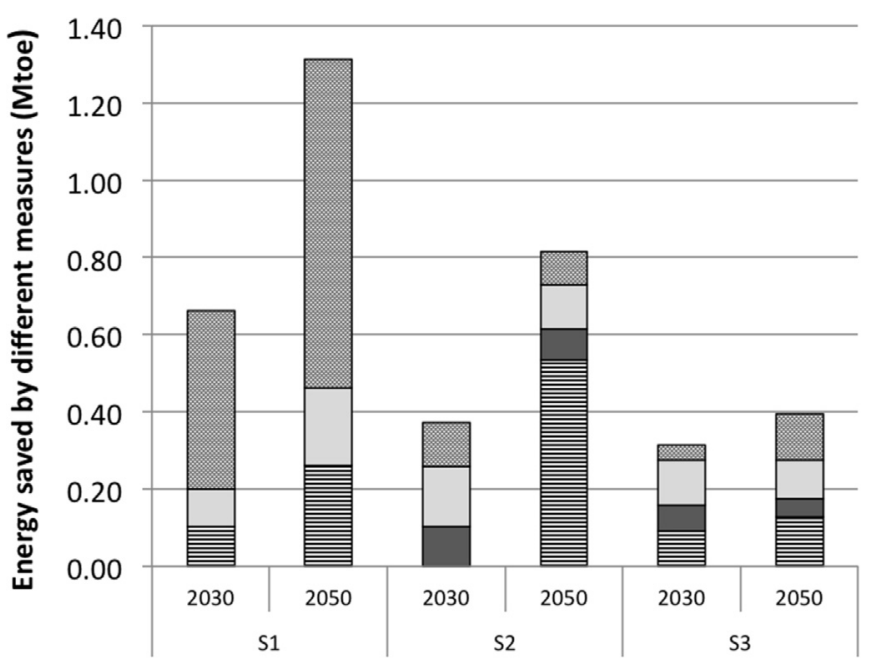

目Due to New Build Technology $\square$ Due to Operational change $\square$ Due to Retrofit Technology $\quad$ Due to speed

Fig. 4. Energy saved through operational and technological measures across the scenarios (Mtoe).

Table 4

Summary of per cent changes to transport demand with reference to 2010 across the scenarios.

\begin{tabular}{|c|c|c|c|c|c|c|}
\hline & \multicolumn{2}{|l|}{$\mathrm{S} 1$} & \multicolumn{2}{|l|}{$\mathrm{S} 2$} & \multicolumn{2}{|l|}{ S3 } \\
\hline & 2030 & 2050 & 2030 & 2050 & 2030 & 2050 \\
\hline Tonnage & $-17 \%$ & $-13 \%$ & $-31 \%$ & $-26 \%$ & $-22 \%$ & $-15 \%$ \\
\hline Transport Work & $+21 \%$ & $+60 \%$ & $-16 \%$ & $-1 \%$ & $-40 \%$ & $-64 \%$ \\
\hline Haul length & $+47 \%$ & $+84 \%$ & $+21 \%$ & $+34 \%$ & $-23 \%$ & $-58 \%$ \\
\hline
\end{tabular}

Given that slow steaming could essentially lead to a reconfiguration of the shipping system, incorporating new slow steaming policy measures would also require complementary policies to be pursued by shipping organisations and buy-in from shipping actors. In the short-term, voluntarily adoption of slow-steaming is likely preferable to widespread mandatory speed limits. However, given the urgency associated with the $\mathrm{CO}_{2}$ constraints embedded within the $2{ }^{\circ} \mathrm{C}$ goal, policies mandating speed limits are in S1 assumed necessary in conjunction with the widespread availability of virtual arrival services. The apparent inability of voluntary measures to secure deep emission reductions within 


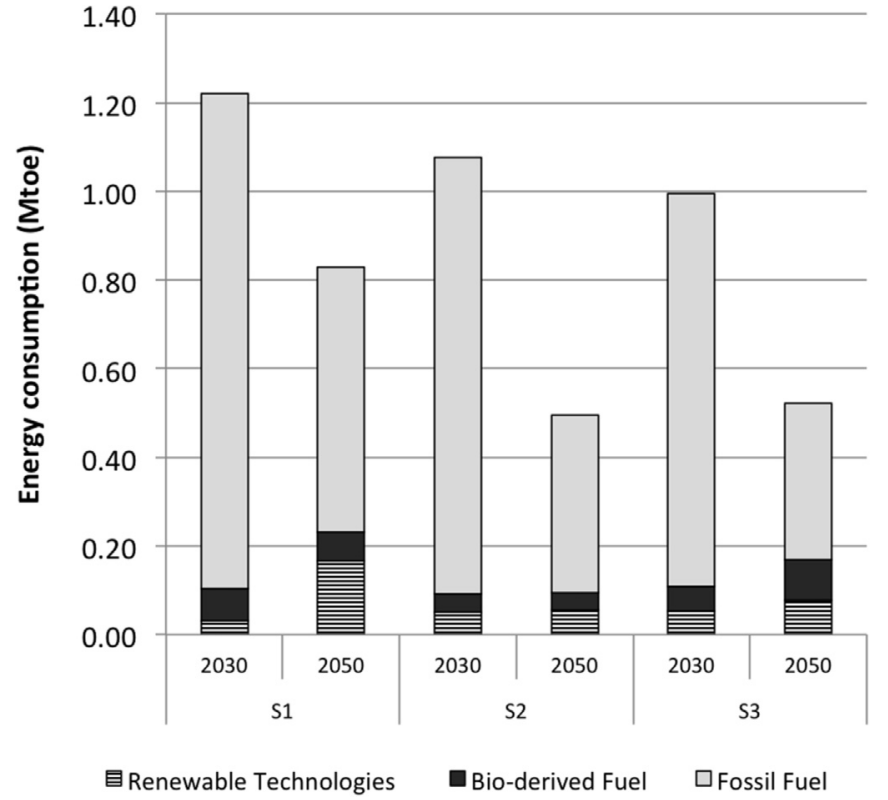

Fig. 5. Energy consumption by energy type across the scenarios. (Mtoe).

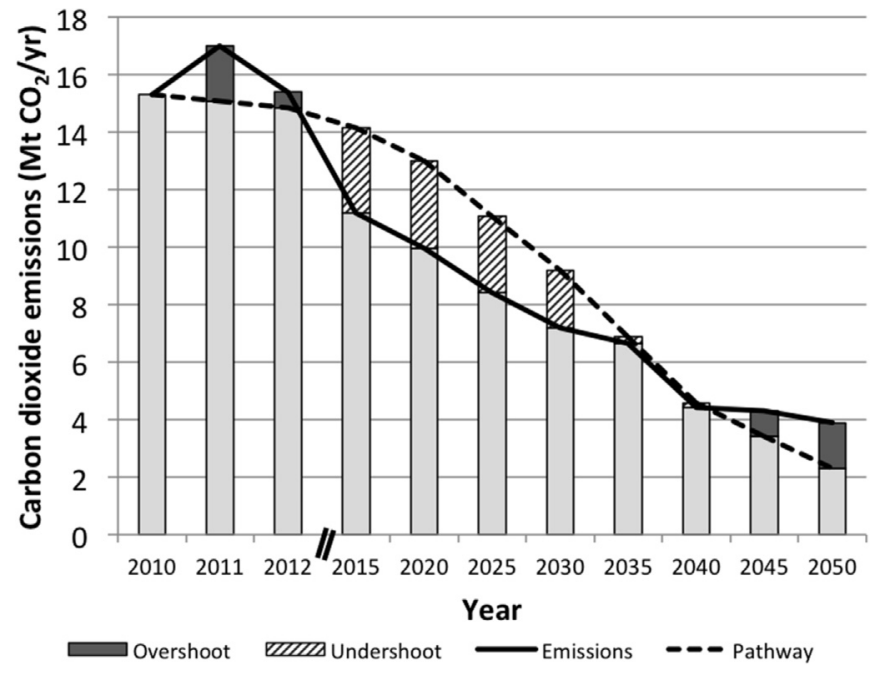

Fig. 6. Cumulative emission pathways for $\mathrm{S} 1\left(\mathrm{Mt}^{\mathrm{CO}}\right)$.

the transport sector has previously been presented as advocating for more diverse policy measures [18].

\subsection{Changing transport demand}

Given the high proportion of fossil fuel energy carriers within UK imports [12] it is unsurprising that decarbonising the energy system plays a significant role in reducing demand for UK shipping and reducing $\mathrm{CO}_{2}$ emissions [22]. This is not only relevant to UK trade however, as at a global level, decarbonisation in line with the Paris Agreement (as opposed to existing Nationally Determined Contributions or indeed the DECC scenarios used here) is anticipated to have profound implications for trade, given the high proportion of all shipped goods associated with fossil fuels $[32,36]$. Each scenario here, presents a different vision for how overall demand could change. S2 does not have the same increase in freight work as S1, reflecting a reduction in both the tonnage shipped and the haul length. Compared to S1, the Markal decarbonisation scenario in S2 implies reduced fossil fuel imports, particularly for liquid gas. Furthermore, this scenario does not include continued growth in containerised goods as in S1. This highlights the importance of viewing traded quantities and distances in

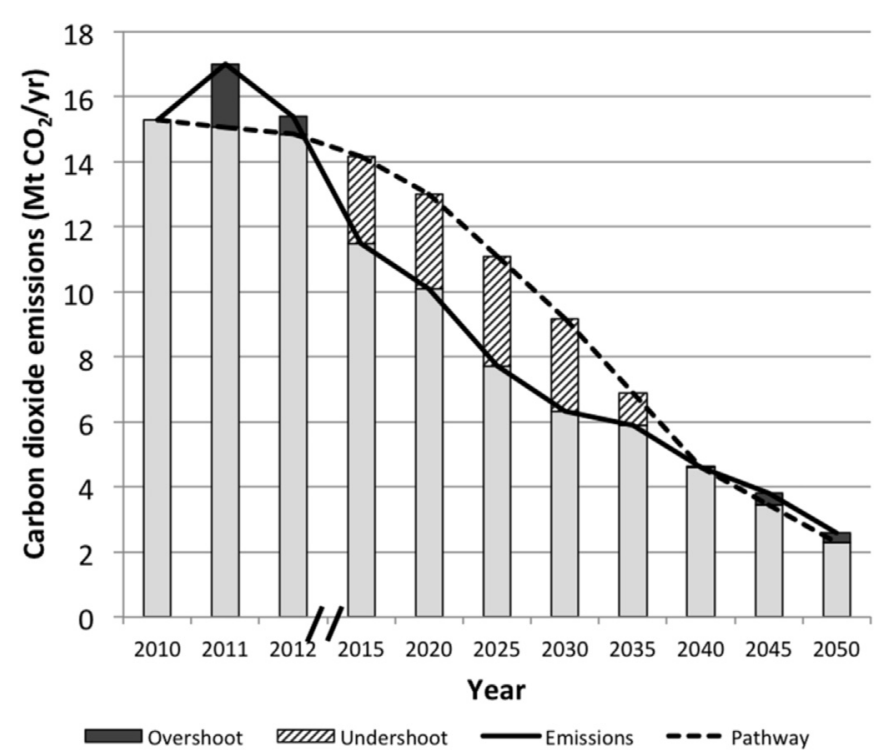

Fig. 7. Cumulative emission pathways for $\mathrm{S} 2\left(\mathrm{Mt} \mathrm{CO}_{2}\right)$.

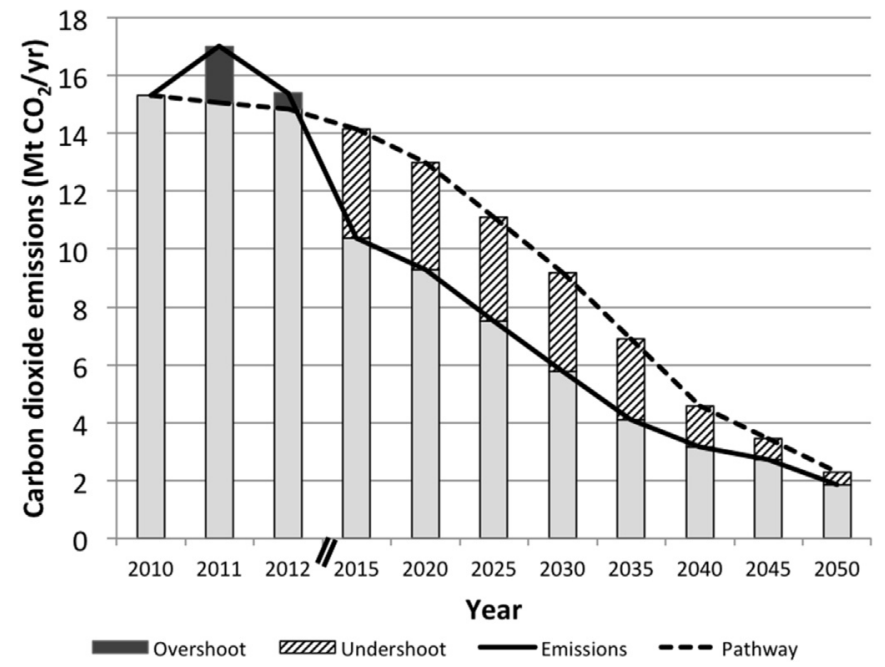

Fig. 8. Cumulative emission pathways for $\mathrm{S} 3\left(\mathrm{Mt} \mathrm{CO}_{2}\right)$.

tandem as illustrated in S1, containers not only represent the fastest growing cargo type in terms of quantity but by 2050 , have the second highest haul length after liquid gas. S3 has the largest reduction in demand for freight work by 2050 . It could be argued that, despite the lack of a single specific, impactful, $\mathrm{CO}_{2}$ reduction technology or operational policy measure, this scenario represents a more fundamental departure from practices in 2010 , as it effectively reverses recent trends in globalisation. While the majority of UK maritime trade was sourced within the EU in 2014 [12], the very nature of trade, and indeed implications of Brexit, mean that the majority of freight work is actually associated with the deep-sea trade. The reduction in freight work evident in S3 is mostly attributable to a reduction in haul length. Nevertheless, large changes in fossil fuel trade due to the successful deployment of policies to significantly decarbonise the UK land-based energy system, has a major influence on the demand for UK shipping.

While the scenarios present feasible options for shifts in demand, they deliberately do not make explicit what all the feasible policy mechanisms for change could be. One notable suite of measures that could influence demand, and that have received attention in recent IMO discussions are Market Based Measures (MBMs). However, in line with the comment in Section 4.1 that voluntary measures risk delivering mitigation at a pace at odds with the Paris Agreement's goals, MBMs are similarly questioned (Bows-Larkin, 2014). Moreover, when preliminary 
analysis within the follow-on EPSRC project 'Shipping in Changing Climates' considers the price of carbon necessary to influence the sector in line with a $2{ }^{\circ} \mathrm{C}$ goal, results indicate considerably higher prices than any postulated within IMO discussions.

\subsection{Technological solutions}

Amongst a wide range of technologies, one particular measure that has a prominent impact is the deployment of nuclear propulsion in S2. By 2050 it is assumed that over half of the S2 global shipping fleet comprise nuclear vessels. Given that container ships generally transport material for a number of clients, including consumers, it is assumed that a longer period of time is necessary to gain widespread customer acceptance. However it could be argued that the speed benefit afforded by nuclear ships could make it an attractive proposition.

As expressed by shipping stakeholders during scenario construction (High [31]), the pace of technology innovation and deployment for land-based applications that can be adapted for marine use will influence the rate of penetration of the global fleet. To achieve the levels of global fleet penetration necessary for these constrained cumulative $\mathrm{CO}_{2}$ budgets, healthy levels of turnover must be achieved. Maintaining (or increasing) ship turnover across extended periods has historically proved difficult especially during periods of market downturn [36] thus additional policy measures to drive fleet renewal are required. The widespread uptake of new technologies will necessitate policies incentivising retrofitting and new build options, ideally at a global scale. The EEDI reflects a global efficiency target for new build vessels that can in theory be met by changes to engine size alone, although clearly other technical measures influence the EEDI [3]. Policies that provide finance and/or subsidises for new technologies can incentivise innovative solutions. This may assist in combating the 'landlord tenant problem' whereby the ship owner incurs installation costs but may not benefit from fuel savings. The requirement of verified vessel efficiency ratings, taking into account the effect of new technologies may incentivise the installation of such technologies through enhancing the competitive resale value of a vessel. Furthermore, the emergence of new technologies will likely require adequate standards agreed upon by the IMO and ship classification companies. In the case of nuclear, changes to the current nuclear regulatory model would be needed to ameliorate the cost barrier to smaller nuclear reactors [17].

The longer it takes a fundamentally different technology to enter the market, the greater the onus on more conventional $\mathrm{CO}_{2}$ mitigation measures during the preceding period. In S2, prior to the emergence of nuclear vessels, necessary decarbonisation rates are achieved by combining changes to transport demand, technological, operational and renewable energy options. Similarly S3 illustrates that no single supply side solution dominates $\mathrm{CO}_{2}$ mitigation. However, the assumption of multiple technologies operating in tandem necessitates a caveat. Crucially, the literature from which the energy saving potential of different technologies is taken tends to view technological solutions in isolation. In the absence of specific information from sea trials or modelling exercises it is difficult to predict how different (but compatible) technologies interact, particularly if speed is reduced. While this may suggest that for a given technology, theoretical maximum increase in relative energy efficiency may be difficult to achieve, the potential benefits of employing technologies, such as wind assistance in conjunction with slow steaming, can none-the-less have a pronounced impact on absolute energy demand. In other words, reducing operational demand can enhance the proportional benefits of technological options even if they may not operate optimally.

\subsection{Changes to the wider system}

The scenarios emphasise important interdependencies around how shipping decarbonisation requires wider system support. For example, global supply chains must be capable of accommodating speed reduc- tions over all journey legs. A radical technological change, such as the deployment of nuclear propulsion, is contingent on both the development of new technology such as modular reactors, and addressing wider challenges at a global scale such as regulation, public acceptance and licensing for safe operation [17]. Furthermore it could be argued that fleet-wide retrofit reflects the emergence of an entirely new global market within the wider shipping system, in conjunction with new ship construction and sale, cargo movement, second hand vessel market and eventual recycling of vessels. This would require adequate dry-docking services around the world and opportunities for demonstrating new technologies [7], all of which likely require further policy implementation. Moreover, widespread technological uptake necessitates extensive knowledge exchange across the areas of technology design and ship operation to ensure newly fitted technologies are operated correctly. The importance of incentivising early-adopters should not be overstated given the inherently risk-adverse nature of the sector (High [31]). In the short term, a means of sharing risk between stakeholders is likely to be necessary to facilitate widespread uptake of different technologies. For example, through the increased use of 'smart contracts', charter arrangements can be amended to spread the costs (e.g. capital) and benefits (e.g. fuel saving) between ship owners and charterers [20]. Such mechanisms seek to mitigate the split incentives evident in the sector and allow for greater flexibility in, for example, operating speed.

Changes proposed within S3 are dependent on market accessibility by short sea shipping to satisfy demand, as most demand for seaborne trade is satisfied within Europe. As well as highlighting the importance of trading distance, the changes in this scenario and unlike the others, are contingent on wider market change, namely a reversal of globalisation. In conjunction with uncertainty in marine fuel prices, 'near sourcing' production closer to end markets becomes more attractive. Key European countries would, in this case, transition to being net exporters of many commodities.

\section{Conclusions}

Three original and distinct scenarios interpret a $2{ }^{\circ} \mathrm{C}$ temperature goal for UK imported and domestic shipping, set within a global supply chain context. The scenarios illustrate how diverse emission mitigation measures that are adopted in the near term, and continually built upon, can feasibly mitigate $\mathrm{CO}_{2}$ emissions in line with the strict cumulative $\mathrm{CO}_{2}$ pathways associated with $2{ }^{\circ} \mathrm{C}$. Although a UK perspective is used, the global nature of the shipping industry means that the implications are relevant across global trade. What emerges clearly from the scenarios, is that satisfying the constrained cumulative $\mathrm{CO}_{2}$ budget associated with $2{ }^{\circ} \mathrm{C}$ requires action in the short-term across the fleet and manifested in unprecedented change.

The scenarios illustrate for the first time that while there are numerous measures available to contribute towards sectoral decarbonisation, no single measure is sufficient. Changes will be necessary across demand, operations and technology, and wider global system change is also key. Nevertheless, it is difficult to foresee how decarbonisation will be achieved without speed reduction in the near term, and while carbon-intensive fuels continue to be widespread. Moreover, speed reduction offers co-benefits when coupled with extensive retrofit of other energy saving measures including renewable technologies for propulsion. Crucially though, the extent of the speed reduction pursued will have consequences for global supply chain management and structure of the global fleet.

It is commonly assumed within the sector that demand will continue to grow. However, without an absolute reduction in shipping demand and/or transport work, the constraints of a $2{ }^{\circ} \mathrm{C} \mathrm{CO}_{2}$ budget require even greater levels of mitigation, including low-carbon technologies being widely deployed well before 2050. This is in addition to anticipated continual improvement in the energy efficiency/carbon intensity of the fleet. The scenarios highlight that reducing transport work through operational measures - for instance by trading with 
partners closer to the goods' destination - leads to even greater reductions in $\mathrm{CO}_{2}$ when complemented by combinations of energysaving technologies. Additionally, mitigation must target elements of the shipping sector responsible for the largest proportions of $\mathrm{CO}_{2}$, such as containerships. While continual improvement in carbon intensity may be difficult to achieve given the cyclical nature of the shipping sector [36], it is clear that new stringent policies, such as regulatory or financial incentives, will be necessary to mitigate against the fundamental complexity and volatility of the industry and drive rapid, sustained changes throughout the global fleet.

By 2050 , an adequately decarbonised shipping sector will look very different to the present system and if achieved, it will be within the context of wider energy system decarbonisation across the globe. Thus policies that deliver major transitions in domestic energy systems will have important co-benefits for the shipping sector's $\mathrm{CO}_{2}$ mitigation. However, what has become clear from this new analysis, is that if appropriate policy driven mitigation measures are not implemented across demand, technology and operations in the near term, remaining within the $\mathrm{CO}_{2}$ budget becomes much more challenging, if not impossible, in later years. This conclusion is applicable not only to UK shipping, but the shipping system as a whole.

\section{Acknowledgements}

Please note that this research has been funded by the UK Engineering and Physical Sciences Research Council, EP/H02011X/1.

\section{References}

[1] M.R. Allen, D.J. Frame, C. Huntingford, C.D. Jones, J.A. Lowe, M. Meinshausen, N. Meinshausen, Warming caused by cumulative carbon emissions towards the trillionth tonne, Nature 458 (2009) 1163-1166.

[2] K. Anderson, A. Bows, Executing a Scharnow turn: reconciling shipping emissions with international commitments on climate change, Carbon Manag. 3 (2012) 615-628.

[3] E.E. Attah, R. Bucknall, An analysis of the energy efficiency of LNG ships powering options using the EEDI, Ocean Eng. 110 (2015) 62-74.

[4] A. Bows-Larkin, C. McLachlan, S. Mander, R. Wood, M. Roeder, P. Thornley, E. Dawkins, C. Gough, L. O'Keefe, M. Sharmina, The importance of non-CO emissions in carbon management, Carbon Manag. 5 (2014) 193-210.

[5] A. Bows-Larkin, S. Mander, P. Gilbert, M. Traut, C. Walsh, K. Anderson, High Seas, High Stakes, High Seas Final Report, Tyndall Centre for Climate Change Research, 2014.

[6] Ø. Buhaug, J.J. Corbett, Ø. Endresen, V. Eyring, J. Faber, S. Hanayama, D.S. Lee, H. Lindstad, A.Z. Markowska, A. Mjelde, D. Nelissen, J. Nilsen, C. Pålsson, J.J. Winebrake, W.Q. Wu, K. Yoshida, Second IMO GHG study 2009, International Maritime Organization (IMO), London, UK, 2009.

[7] D. Caprice, F. del Castillo, Identification of skills and technologies required to consistently use the new techniques for retrofit (2013) (Eco-refitec project report for FP7).

[8] CCC, Review of UK shipping emissions. Committee on Climate Change, London, 2012 .

[9] J.J. Corbett, H. Wang, J.J. Winebrake, The effectiveness and costs of speed reductions on emissions from international shipping, Transp. Res. Part D: Transp. Environ. 14 (2009) 593-598.

[10] DECC, 2050 Pathways. Department of Energy and Climate Change. Retrieved from 2050-calculator-tool.decc.gov.uk/, 2013.

[11] M.S. Eide, T. Longva, P. Hoffmann, $\varnothing$. Endresen, S.B. Dalsøren, Future cost scenarios for reduction of ship $\mathrm{CO}_{2}$ emissions, Marit. Policy Manag. 38 (2011) 11-37.

[12] Eurostats, Maritime trade statistics. Retrieved from 〈http://ec.europa.eu/eurostat〉, 2014.

[13] V. Eyring, H.W. Köhler, J. Van Aardenne, A. Lauer, Emissions from international shipping: 1, last 50 years. J. Geophys. Res.: Atmospheres (2005) 110 (D17).

[14] V. Eyring, H.W. Köhler, A. Lauer, B. Lemper, Emissions from international shipping:
2, Impact Future Technol. Scenar. 2050. J. Geophys. Res.: Atmospheres (2005) 110 (D17).

[15] P. Gilbert, A. Bows, Exploring the scope for complementary sub-global policy to mitigate $\mathrm{CO}_{2}$ from shipping, Energy Policy 50 (2012) 613-622.

[16] P. Gilbert, A. Bows-Larkin, S. Mander, C. Walsh, Technologies for the high seas: meeting the climate challenge, Carbon Manag. 5 (2015) 1-15.

[17] B.S. Haas, Strategies for the success of nuclear powered shipping. Presentation to the Connecticut Maritime Association, March 2014, 2014.

[18] J. Higham, S.,A. Cohen, T. Cavaliere, A. Reis, W. Finkler, Climate change, tourist air travel and radical emissions reduction, J. Clean. Prod. 111 (Part B) (2016) 336-347.

[19] IMO, International Maritime Organization, Position Statement Control Greenh. Gas. Emiss. Ships Ad-Hoc Work. Group Long.-Term. Coop. Action. UN, Geneva, Switz. (2011) (2011).

[20] S. Jafarzadeh, B.I. Utne, A framework to bridge the energy efficiency gap in shipping, Energy 69 (2014) 603-612.

[21] Man Diesel and Turbo, Slow Steaming Practices in the Global Shipping Industry. Results of a survey conducted by MAN PrimeServ in late 2011 among representatives of the global container, bulk and tanker shipping industry. MAN PrimeServe, 2012.

[22] S. Mander, C. Walsh, P. Gilbert, M. Traut, A. Bows, The implications of a low carbon energy transition for the shipping sector, Carbon Manag. 3 (6) (2012) 601-614, http://dx.doi.org/10.4155/cmt.12.67.

[23] S.L. Mander, A. Bows, K.L. Anderson, S. Shackley, P. Agnolucci, P. Ekins, The Tyndall decarbonisation scenarios-part I: development of a backcasting methodology with stakeholder participation, Energy Policy 36 (2008) 3754-3763.

[24] M. Morooka, Letter to Christine Lagrande, Managing Director of IMO from the Chair of the International Chamber of Shipping, 2012.

[25] N. Nakicenovic, R. Swart (Eds.), Special Report on Emissions Scenarios. Special Report of IPCC Working Group III, Cambridge University Press, UK, 2000.

[26] K.C. Nam, K.S. Kwak, M.S. Yu, Simulation study of container terminal performance, J. Waterw. Port. Coast. Ocean Eng. 128 (2002) 126-132.

[27] A. Paxian, V. Eyring, W. Beer, R. Sausen, C. Wright, Present-day and future global bottom-up ship emission inventories including polar routes, Environ. Sci. Technol. 44 (2010) 1333-1339.

[28] M. Placet, J.F. Clarke, Emerging Technology Road Maps: the Batelle Approach, The Joint Global Change Research Institute, MD, USA, 1999.

[29] J. Quist, P. Vergragt, Past and future of backcasting: the shift to stakeholder participation and a proposal for a methodological framework, Futures 38 (2006) 1027-1045.

[30] J. Robinson, Future subjunctive: backcasting as social learning, Futures 35 (2003) 839-856.

[31] High Seas, 'A new ship on the horizon?' Report of a stakeholder workshop, Tyndall Centre, University of Manchester, 2013.

[32] M. Sharmina, C. McGlade, P.J. Gilbert, A. Larkin, , 2017. Global energy scenarios and their implications for future shipped trade, submitted to Marine Policy and personal communication.

[33] Y. Shi, Reducing greenhouse gas emissions from international shipping: is it time to consider market-based measures? Mar. Policy 64 (2016) 123-134.

[34] T.W.P. Smith, J.P. Jalkanen, B.A. Anderson, J.J. Corbett, J. Faber, S. Hanayama, E. O'Keeffe, S. Parker, L. Johansson, L. Aldous, C. Raucci, M. Traut, S. Ettinger, D. Nelissen, D.S. Lee, S. Ng, A. Agrawal, J.J. Winebrake, M. Hoen, S. Chesworth, A. Pandey, Third IMO GHG Study 2014, International Maritime Organization, London, 2014.

[35] T.F. Stocker, D. Qin, G.K. Plattner, M. Tignor, S.K. Allen, J. Boschung, A. Nauels, Y. Xia, B. Bex, B.M. Midgley, Climate change the physical science basis. Contribution of working group I to the fifth assessment report of the Intergovernmental Panel on Climate Change, Geneva, 2013.

[36] M. Stopford, Maritime Economics, 3rd ed., Routledge, New York and London, 2009.

[37] UNCTAD, Review of Maritime Transport, United Nations Commission on Trade and Development, Switzerland, 2013.

[38] UNFCCC, Adoption of the Paris Agreement, draft decision-/CP.21. Conference of the Parties, Twenty-first session Paris, 2015. United Nations Framework Convention on Climate Change, 2015.

[39] D.P. van Vuuren, J. Edmonds, M. Kainuma, K. Riahi, A. Thomson, K. Hibbard, G.C. Hurtt, T. Kram, V. Krey, J.F. Lamarque, T. Masui, M. Meinhausen, N. Nakicenovic, S. Smith, S.K. Rose, The representative concentration pathways: an overview, Clim. Change 109 (2011) 5-31.

[40] C. Walsh, S. Mander, Contextualising the drivers for trade: some lessons from historical case studies, Mar. Policy (2016), http://dx.doi.org/10.1016/j.marpol. 2016.04.004.

[41] C. Walsh, A. Bows-Larkin, P. Gilbert, S. Mander, M. Traut, A new method for estimating national-scale $\mathrm{CO}_{2}$ from shipping: preliminary estimates from a UK study (Low carbon shipping conference), Newcastle University, 2013. 